
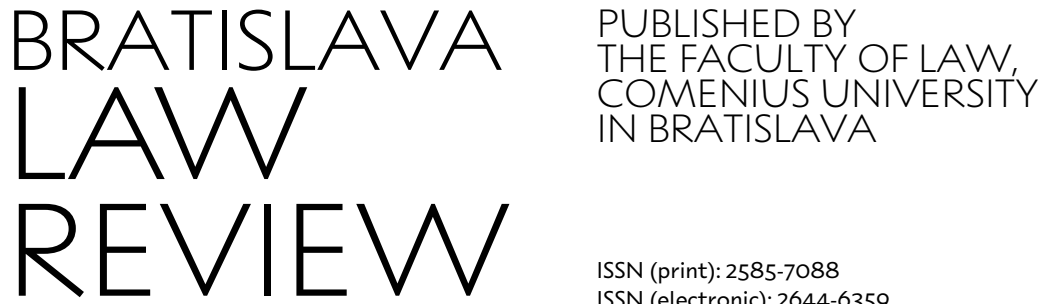

ISSN (print): $2585-7088$

ISSN (electronic): 2644-6359

\title{
INTERPRETING LAW THROUGH INTERNATIONAL JUDICIAL DIALOGUE BY POLISH COURTS / Magdalena
}

\author{
Matusiak-Frącczak
}

\section{Magdalena Matusiak-Fracczak, PhD. University of Łódź, Faculty of Law and Administration; ul. Kopcińskiego 8/12; 90-232 Łódź: Poland: \\ mfracczak@wpia.uni.lodz.pl ORCID: 0000-0002-6736-8008}

The paper was originally presented at "The XIVth CEENJ Conference: Jurisprudence in Central and Eastern Europe, Bratislava, 12-13 September 2019".

Submitted: 17 May 2020

Accepted: 18 September 2020

Published: 31 December 2020

\begin{abstract}
International judicial dialogue is a new method of law interpretation that gains popularity in analyses of legal scholars and still raises a lot of doubts both on its existence as well as its definition. This paper will deal with the application of this technique by Polish courts. In the first place, it will be explained what international judicial dialogue actually means. Afterwards, the paper will in detail discuss problems connected to the use of this method on the basis of decisions of Polish courts, first, by presenting examples of a proper, decorative and failed dialogue, and then by emphasizing complications caused by this method in the Polish jurisprudence. It will be also explored whether there exists a real dialogue, meaning that not only Polish courts receptively refer to judgments of international and foreign courts, but there is also some level of reciprocity in those references. At the end of the paper, the advantages and disadvantages of this method will be deliberated. In this part, I will suggest some solutions permitting mitigation of some adverse effects $s$ of this technique.
\end{abstract}

Key words: dialogue; international judicial dialogue; jurisprudence; courts; case-law; globalisation; comparative constitutionalism; Polish law

\section{Suggested citation:}

Matusiak-Frącczak, M. (2020). Interpreting Law Through International Judicial Dialogue by Polish Courts. Bratislava Law Review, 4(2), 49-70. https://doi.org/10.46282/blr.2020.4.2.181

\section{INTRODUCTION}

The progressive internationalisation of every aspect of human life and relations is an undeniable fact. Living in a globalised world has its effect on economic and financial relations, communication, families and, of course, on national laws. Using various instruments, international law encroaches in different ways into domestic legal orders. Nevertheless, the efficiency of international law depends mostly on its application and interpretation by national courts. Moreover, international relations and developments also influence the domestic legal system, as they create new legal problems that need to be solved by national law or its interpretation. In these new problematic areas, national courts, lacking any previous national jurisprudence, might be tempted to look for solutions in foreign legal systems and their case-law.

And here is where the shoe pinches. It is necessary to determine how national courts find a correct and proper application and interpretation of international law, as well as accurate international sources of inspiration for interpretation of new legal problems 
arising in domestic laws, especially in the area of human rights (L'Heureux-Dubé, 1998, p. $21,24-25)$. It is obvious that this cannot be done by a mere reference to the text of international or foreign law, nor by decoding the text of international or foreign legal norm solely on the basis of the concepts and ideas of national laws or existing domestic jurisprudence, as this interpretation should be as far as possible consistent among courts of different states (Kirby, 2008, p. 172). This analysis requires a more profound exploration of international and foreign law, including case-law, and here is the place for international judicial dialogue as a method of interpretation, as traditional domestic ways of interpreting law do not suffice. This poses a serious question, i.e. whether national courts dispose with necessary tools and preparation to carry out this task correctly while avoiding misunderstanding and misinterpretation.

As the issue at stake is very complicated and might vary among different states, this article concentrates on the practice of the Polish judiciary and its paths, as well as abilities to face new challenges stemming from international law, developments and relations. The first part of this paper will focus on presentation of some general and introductory remarks on international judicial dialogue. Next part of the paper will be dedicated to deliberations on international judicial dialogue before the Polish courts. It includes discussing examples of proper, decorative and failed dialogue performed by different instances of the Polish judiciary. Afterwards, I will assess international judicial dialogue as a method of interpretation used by the Polish courts. This comprises both correctness of this technique as applied by the Polish courts, as well as influence of the Polish case-law on jurisprudence of international and foreign courts. In conclusion, I will point out some advantages and disadvantages of the international judicial dialogue as a method of legal interpretation, as well as possible solutions of minimalizing the risk connected to the application of international judicial dialogue.

\section{INTERNATIONAL JUDICIAL DIALOGUE - GENERAL REMARKS}

The first question to answer is how we can define international judicial dialogue. The starting point of this exploration will be definitions of dialogue contained in different dictionaries. As the term "dialogue" in all dictionaries has different meanings for diverse uses, I will focus on the definitions connected to the aim of this paper.

In Thesaurus Dictionary "dialogue" is described as "an exchange of ideas and opinions on a particular issue, especially political or religious issue, with a view to reaching and amicable agreement or settlement". Merriam-Webster Dictionary shortly defines "dialogue" as "an exchange of ideas and opinions". According to Cambridge Dictionary "dialogue" is "a serious exchange of opinion, esp. among people or groups that disagree". Another definition is presented in Collins Dictionary where "dialogue" means "a communication or discussion between people or groups of people such as governments or political parties". Finally, Oxford Learner's Dictionary, describes "dialogue" as "a formal discussion between two groups or countries, especially when they are trying to solve a problem, end a disagreement, etc."

One might also point out different definitions of international judicial dialogue in publications of legal scholars. L'Heureux-Dubé noticed that the process of international legal influence changed overtime from reception to dialogue. Reception means only that reasoning of some international and foreign jurisdictions was applied by others, namely domestic courts. Within international judicial dialogue, judges look into numerous sources when deciding how to interpret their constitutions and deal with new problems, they are reading and discussing each other's jurisprudence (1998, p. 17-18, 21).

Relying on the work of L'Heureux-Dubé, Grove defined international judicial dialogue as a possibility for domestic courts deciding on a particular substantive legal 
issue to look for interpretative guidance encompassed not only in international treaties but also in decisions of supranational and foreign courts that have addressed similar legal question. This might be connected with a response of an interlocutor, if international and foreign courts facing comparable legal issues refer to domestic courts' decisions. She also underlines that the opinion of international community does not overcome domestic law, it is only a helpful source of inspiration permitting the analysis of legal development of similar issue in jurisprudence of foreign courts $(2001$, p. 2049, 2052).

In his paper, Kirby defines this dialogue as comparative constitutionalism, meaning invoking decisions of international and foreign courts by national courts which concern both the substance of the law and its doctrines and procedures for conducting trials. He emphasizes that international judicial dialogue does not serve incorporating foreign and international laws into domestic legal system, as it is only an interpretative tool $(2008$, p. 171-172, 184, 186).

We may also find an opinion that the notion "dialogue" enjoys variety of meanings, depending on circumstances or the author. On the basis of numerous definitions in legal publications, Meuwese and Snel construct their own definition of "dialogue", i.e. a sequel of implicitly or explicitly shaped communications back and forth between two or more actors characterized by the absence of a dominant actor - or at least by a bracketing of dominance -, with the shared intention of improving the practice of interpreting, reviewing, writing or amending constitutions (2013, p. 124-126). Yet it needs to be born in mind that these authors in their paper discussed "dialogue" not only between courts but also between other institutions and bodies. For the purposes of the present deliberations, it is assumed that "dialogue" is limited to judicial bodies, as the study focuses on international judicial dialogue only, other authoritative instances are excluded from the research.

Law and Chang, in general, consider that the notion "dialogue" is conceptually and empirically an inapt metaphor for the comparative analysis performed by constitutional courts. This conclusion is based on the assumption that dialogue is supposed to be inclusive and involve reciprocal engagement of interlocutors in the dispute and this element is usually missing and possible referrals are mostly made to judgments of elite courts $(2011$, p. 527, 531, 534). Nevertheless, the authors in their paper also included $\mathrm{s}$ a definition of international judicial dialogue, constructed on the basis of publications of other legal scholars. ${ }^{1}$ According to this definition, this dialogue is the citation of foreign law by constitutional courts that both reflects and fosters the emergence of a common global enterprise of constitutional adjudication (Law and Chang, 2011, p. 523, 528).

From the above mentioned definitions, one may choose elements that might be relevant in creating a definition of international judicial dialogue. Definitely, it is an exchange of ideas and opinions serving solely interpretation of law purpose. As it concerns legal matters, high standard of seriousness is required. Yet, the deliberated issues usually are neither political nor religious, although in some specific areas there might exist political or religious elements in the background of a legal dispute. However, as it will be indicated in the following parts of the paper, it is not necessary that there occurs any disagreement between the discussing subjects, namely between international and national courts, as all of them might represent a similar attitude towards a given problem. Although the dialogue should include an exchange of opinions between interlocutors, in case of international judicial dialogue, this may not always happen. One court may refer to decisions of other courts, yet the reciprocity is not required. Despite the fact that some legal scholars limit the international judicial dialogue only to

\footnotetext{
${ }^{1}$ However it needs to be emphasized that Law and Chang criticise this definition.
} 
constitutional courts, it needs to be underlined that it concerns every type and level of courts.

Therefore, in this paper, the notion "international judicial dialogue" should be understood as references and examination of judgments of international courts or domestic courts of other states with the aim of solving a legal problem. On the basis of the examples presented in the following parts of this paper, we may divide the judicial dialogue into four categories:

1. proper dialogue - courts refer to accurately collected case-law of other courts and analyse it properly from the methodological point of view;

2. fake or decorative dialogue - courts pretend to refer to the case law of other courts but, in fact, they just decorate the reasoning by random references to inappropriately collected and inaptly analysed decisions;

3. failed dialogue - courts miss the opportunity to refer to the case law of other courts, where one should reasonably expect that such jurisprudence is presented;

4. other types of dialogue - dialogue non-classifiable in other categories (Górski, 2017, p. 235).

A study concerning international judicial dialogue is problematic due to several factors. It is highly restricted by the availability of the research material. Although different courts issue numerous judgments every year, only a very scarce minority of them contains elements of international judicial dialogue. Moreover, not all of them are published and accessible through electronic search engines, including both general ones, like Google, etc. and those available for law professionals. That is why, as suggested by Law and Chang (2011, p. 527), it is inappropriate to use quantitative research methods, meaning statistical citations to foreign law, as they need to be supplemented with qualitative approaches. These authors recommend interviewing judges, however, this study will focus on a deep analysis of the entire texts of judicial decisions that use the technique of international judicial dialogue.

\section{INTERNATIONAL JUDICIAL DIALOGUE BEFORE POLISH COURTS}

As it was stated at the beginning, the paper will concentrate on the use of international judicial dialogue by Polish courts as a method of interpretation of international and domestic law. The publication is not limited to constitutional dialogue, therefore, I will analyse decisions of all types and levels of the Polish judiciary. In this part of the paper, I will briefly present selected examples of proper, decorative and failed judicial dialogue.

\subsection{Structure of the Polish judicial system}

Before I start exploration of the application of international judicial dialogue by Polish courts, it is necessary to present, in short, the structure of the Polish judiciary.

In Poland, there are three types of jurisdiction. First of all, the Constitutional Tribunal is empowered to decide on compatibility of legal acts situated at lower levels of hierarchy of sources of Polish law with the acts situated above them (Polish Constitution, Art. 188) and on division of powers between central constitutional organs of the state (Polish Constitution, Art. 189). ${ }^{2}$

\footnotetext{
${ }^{2} \mathrm{~A}$ detailed scrutiny of judgments of the Polish Constitutional Tribunal is contained in Skomerska-Muchowska (2017).
} 
Cases concerning criminal law and civil law, including family law, labour and social security law are decided by Polish general courts. ${ }^{3}$ A constitutional standard is that cases are decided by two instances. However, in limited areas, they might be decided by the Supreme Court, which acts as a court of cassation. Nevertheless, the Polish law does not classify the Supreme Court as a court being a part of general courts system (Polish Constitution, Art. 175 (1)). For the purposes of this analysis and taking into consideration the value of its judgments for Polish general courts, the Supreme Court shall be considered as such. ${ }^{4}$

Lastly, there are administrative courts, namely the Supreme Administrative Court and 16 Voivodship Administrative Courts (Polish Constitution, Art. 184). ${ }^{5}$

Out of these courts, the Constitutional Tribunal, the Supreme Court, and the Supreme Administrative Court are predestined to use international judicial dialogue as a method of interpretation. It is worth emphasizing that this practice is not limited only to those three courts and the dialogue technique is applied by lower level courts, as well. Main areas of international judicial dialogue used by Polish courts are: human rights, customary international law, European Union law and other non-classifiable areas of law. A very specific area of international judicial dialogue is the preliminary reference procedure before the CJEU. A comprehensive study of this type of dialogue would exceedingly go beyond the scope of this paper, therefore it will not be a subject of deliberations. $^{6}$

\subsection{Proper judicial dialogue}

A proper judicial dialogue takes place when courts refer to accurately collected case-law of other courts, and analyse it properly from methodological point of view. As much as this situation is the most desirable on one hand, on the other it is, unfortunately, the rarest in decision of the Polish judiciary. Taking into consideration the specificity of the proper judicial dialogue, the analysis contained in this part will be a qualitative assessment of selected judgments. This will allow to show the pattern that should be followed by other judges and courts.

The most deep and profound dialogue with foreign courts should be the domain of the Polish Constitutional Tribunal. This is due to the fact that cases decided by the Tribunal require a detailed and exact analysis of fundamental principles of the Polish Constitution which involve comparative deliberations.

In the area of human rights protection, there are several judgments of the Constitutional Tribunal that properly refer and analyse judgments of international and foreign decisions. One of them is the decision in $\mathrm{K} 23 / 11^{7}$ concerning the renegade procedure introduced into the Polish law on aviation. ${ }^{8}$ In short, this procedure was created after the 11 September 2001 terrorist attacks on the World Trade Center and it permitted downing of an airplane hijacked by terrorists, even with passengers on board. At the beginning of its deliberations, the Tribunal emphasized that there is no need to reinterpret human rights and freedoms for the purposes of public safety and protection

\footnotetext{
${ }^{3}$ There are 318 district courts, 45 provincial courts and 11 appellate courts. Cf. Lista sądów powszechnych.

${ }^{4} \mathrm{~A}$ detailed scrutiny of judgments of Polish ordinary courts is contained in Matusiak-Frącczak (2017).

${ }^{5} \mathrm{~A}$ quantitative scrutiny of judgments of Polish administrative courts is contained in Krzemińska-Vamvaka (2017).

${ }^{6}$ More on preliminary reference procedure in Czaplińska (2017).

${ }^{7}$ Poland, Constitutional Tribunal, K 23/11 (30.9.2008).

8 Poland, Law on aviation of 3 July 2002, Polish Official Journal 2002, no. 130/1112.
} 
against terrorist attacks and it is a dominating opinion of case law of foreign courts. ${ }^{9}$ Then it made a study on the standard of protection stemming from the European Convention on Human Rights, as interpreted by the judgments of the European Court of Human Rights concerning right to life. ${ }^{10}$ Lastly, the Tribunal made referral and largely cited the decision in similar case issued by the German Federal Constitutional Court in $2006^{11}$ and adopted the reasoning of its own decision to the statement of reasons delivered by the German Court, including the view that a state cannot legalise an intentional killing of innocent people - hijacked passengers, because all lives, regardless their quality, are protected by the right to life and enjoy equal value.

A very comprehensive analysis of judgments of other constitutional courts of the Member States of the European Union was made by the Polish Constitutional Tribunal in case no. K 32/09, concerning the constitutionality of the Treaty of Lisbon. ${ }^{12}$ The Tribunal referred to the French Constitutional Council's decision of $2007^{13}$ in which the Council emphasized that dome solutions contained in the Treaty of Lisbon may not be sufficient to prevent transferring competences to the European Union in a manner and scope that would violate fundamental conditions of state sovereignty. Moreover, all provisions of the Treaty of Lisbon concerning areas strictly connected to state sovereignty and already present among European Union competences modifying the rules on decision-making process or replacing unanimous decisions by Qualified Majority Voting and deprive France of the possibility of a protest or transfer powers to the European Parliament that is not an emanation of national sovereignty and deprive France of its own initiative are contrary to the French Constitution. Another referral was made to the judgment of the German Federal Constitutional Court of $2009^{14}$ where the Court stated that the European Union, being a union of sovereign states, cannot lead to deprivation of states of their own political debate on Treaty changes, as it is connected with the principle of constitutional identity. The EU membership does not include an automatic acceptance of transfer of powers to the EU and the constitutional courts cannot be deprived of responsibility for warranting constitutional limits of integration authorisation and constitutional identity that is not subject of transfer of powers. After the Czech Constitutional Court, ${ }^{15}$ the Polish Tribunal repeated that after the Treaty of Lisbon the Member States still will be the Herren der Verträge (Masters of the Treaties). The Czech Parliament will be empowered only to accept laws reflecting requirements of the Czech constitutional order, as the EU remains an international organisation and the Member States keep their constitutional identity. Similarly, it was stated by the Hungarian Constitutional Court, ${ }^{16}$ which underlined that the constitutional provisions on the EU membership cannot be interpreted as depriving Hungary of its sovereignty and the democratic rule of law. EU law that is contrary to the

\footnotetext{
9 The Tribunal based its opinion on the analysis of: House of Lords, A v. Secretary of State for the Home Department [2005] UKHL 71; German Federal Constitutional Court [2006] 1 BvR 357/05; Israeli Supreme Court, Public Committee Against Torture on Israel v. The State of Israel et al., Case HCJ 5100/94; Israeli Supreme Court, The Center for the Defence of the Individual v. The Commander of IDF Forces in the West Bank, Case HCJ 3278/01; Israeli Supreme Court, Marab v. The Commander of IDF Forces in the West Bank, Case HCJ 3239/02; US Supreme Court, Rasul v. Bush, Case No. 03-334, 542 US 466 (2004) 321 F. 3d 1134.

${ }^{10}$ ECtHR case-law: Aksoy v. Turkey, case no. 21987/93, judgment of 18.12.1996; Marcx v. Belgium, Young, case no. 7833/74, judgment of 13.6.1979; James and Webster v. UK, case no. 7601/76, 7806/77, judgment of 13.8.1982; Ergi v. Turkey, case no. 23818/94, judgment of 28.7.1998; Velikova v. Bulgaria, case no. 41488/98, judgment of 18.5.2000; Kelly and Others v. UK, case no. 30054/96, judgment of 4.5.2001.

${ }^{11}$ Germany, Federal Constitutional Court [2006] 1 BvR 357/05.

12 Poland, Constitutional Tribunal, K 32/29 (24 November 2009).

${ }^{13}$ France, Constitutional Council, 2007-560 DC (20 December 2007).

14 Germany, Federal Constitutional Court [2009] 2 BvE 2/08, 2 BvE 5/08, 2 BvR 1010/08, 2 BvR 1022/09, 2 BvR 1259/08, and 2 BvR 182/09.

${ }^{15}$ Czechia, Constitutional Court, PI. ÚS 19/08 (26 November 2008).

${ }^{16}$ Hungary, Constitutional Court, 143/2010 (12 July 2010).
} 
material constitutional identity and democratic rule of law will not be binding upon Czechia. The Polish Constitutional Tribunal only mentioned decisions of other constitutional courts declaring the Treaty of Lisbon constitutional. ${ }^{17}$ From all the enumerated judgments, the Polish Constitutional Tribunal concluded that the Treaty of Lisbon is constitutional, however, the importance of constitutions and statutes of the Member States needs to be emphasized as the membership in the European Union cannot lead to the deprivation of the constitutional identity by Member States.

The best example of a Polish decision made on customary international law is the decision on state immunity. In the 2010 Natoniewski case ${ }^{18}$ the Polish Supreme Court was to decide whether the Federal Republic of Germany is protected by state immunity in cases concerning the damage caused during the World War II. The plaintiff, Mr. Natoniewski claimed that there was no possibility to apply state immunity when the state breached jus cogens norm. At that time, there existed opinions claiming that peremptory norm is superior to rules of state immunity and it deprives the rule of state immunity of all its legal effects. ${ }^{19}$

To determine whether Germany could be sued before Polish courts, the Supreme Court referred to numerous international and foreign courts decisions and concluded that there were two opposite approaches to this issue. A lot of foreign courts still considered jurisdictional immunity of state to be absolute, whereas some of them were of the opinion that certain restrictions may apply thereto. From the international instances, the Polish Supreme Court analysed decisions of the European Court of Human Rights, ${ }^{20}$ the Court of Justice of the European Union, ${ }^{21}$ and the International Court of Justice of 2002 in Democratic Republic of the Congo $v$ Belgium. ${ }^{22}$ In this case, the ICJ held that even a violation of jus cogens would not enable the abolition of immunity of the Minister of Foreign Affairs of the Congo while in office. On the other hand, the House of Lords in Pinochet ${ }^{23}$ and the French Cour de Cassation in Qaddafi ${ }^{24}$ decided that in this situation, a state official is not protected by immunity. At that time, Jurisdictional Immunities of the State (Germany $\vee$ Italy: Greece Intervening) case before the $\mathrm{ICJ}^{25}$ was still pending and awaiting a final decision. Therefore, the Polish Supreme Court granted state immunity to Germany and emphasized that it is up to the ICJ and not to the Polish Supreme Court to decide, whether serious violations of human rights constitute an exception to jurisdictional immunity of the state.

\footnotetext{
${ }^{17}$ Latvia, Constitutional Tribunal of Latvia, 2008-35-01 (7 April 2009). Austria, Austrian Constitutional Tribunal, SV 2/08, G 80/08 (30 September 2008).

18 Poland, Supreme Court, IV CSK 465/09 (29 October 2010).

${ }^{19}$ European Court Of Human Rights, Al-Adsani v. the United Kingdom, app. no. 35763/97 (21 November 2001), joint dissenting opinion of judges Rozakis and Caflish, joined by judges Wildhaber, Costa, Cabral Barreto and Vajić.

${ }^{20}$ ECtHR case-law: Al-Adsani v. the United Kingdom, app. no. 35763/97 (21 November 2001); McElhinney v. Ireland, app. no. 31253/96, 21 November 2001; Kalogeropoulou and Others v. Greece and Germany, app. no. 59021/00, 12 December 2002; Waite and Kennedy v. Germany, app. no. 26083/94, 18 February 1999.

${ }^{21}$ CJEU case-law: judgment of 15 February 2007, Lechouritou, C-292/05, ECLI:EU:C:2007:102; judgment of 21 April 1993, Volker Sonntag, C-172/91, ECLI:EU:C:1993:144.

22 ICJ, Case concerning the arrest warrant of 11 April 2000 (Democratic Republic of the Congo v Belgium), judgment, 2002 I.C.J. Rep. 3 (14 February).

${ }^{23}$ United Kingdom, House of Lords, Commissioner of Police for the Metropolis and Others, Ex Parte Pinochet [1999] UKHL 17.

${ }^{24}$ France, Court of Cassation, 00-87215 Qaddafi (13 March 2001).

25 International Court of Justice, Jurisdictional immunities of the State (Germany v Italy: Greece intervening, judgment, 2012 I.C.J. Rep. 99, (3 February).
} 
The Supreme Court examined also decisions of the courts of other states, i.e. of: the United Kingdom, ${ }^{26}$ the United States, ${ }^{27}$ Italy, ${ }^{28}$ and Greece. ${ }^{29}$ It is worth an appreciation that the Court did not limit the scope of its research only to decisions of international bodies, but it made a detailed scrutiny of various foreign courts' case law. Such practice is indispensable when deciding a case based on international customary law.

The Supreme Court concluded that the Polish judicial practice grants to foreign states jurisdictional immunity as a part of customary international law, applicable on the basis of Art. 9 of the Polish Constitution. A violation of jus cogens norms does not mean impliedly that a state renounces its own protection granted by immunity. ${ }^{30}$ The court accentuated that jus cogens exception is not commonly recognized by the international community. ${ }^{31}$

As it was mentioned at the beginning, international judicial dialogue can be used by domestic courts in cases in which they face a new legal problem, e.g. in the field of financial instruments. As an example, we may point out the decision of the Bialystok Appellate Court, ${ }^{32}$ which concerned the contract of the currency option. The Appellate Court started its reasoning by comparing Polish and German laws on the currency option contracts. It found many similarities and decided to analyse in detail the German case law, especially in the area of the bank's informative obligations towards its clients. The Appellate Court found German case-law relevant for interpretation of the Polish regulations and applied the German interpretation to the Polish regulations on currency option contracts. ${ }^{33}$

\footnotetext{
${ }^{26}$ United Kingdom, House of Lords, Jones v. Saudi Arabia [2006] UKHL 26.

27 United States of America, United States Court of Appeals, 9TH Circuit, Liu v. Republic of China [1989] 892 F.2d 1419. United States of America, Supreme Court of the United States, Republic of Austria v. Altmann [2004] 03-13, 541 U.S. 677 (2004) 327 F.3d 1246. United States of America, DC Circuit Court of Appeals, Von Dardel v. Union of Soviet Socialist Republics [1985] 623 F. Supp. 246 (D.D.C. 1985).

${ }^{28}$ Italy, Court of Cassation, Ferrini v. Germany, 5044/2004 (11 March 2004); Civitella, 1072/08 (21 October 2008).

${ }^{29}$ Greece, Special Supreme Court, Perfectory Voiotia v. Germany (Distomo), 111/2000 (4 May 2000); Margellos v. Germany, 6/2002 (17 September 2002).

30 United States of America, United States Court of Appeals, 9TH Circuit, Liu v. Republic of China [1989] 892 F.2d 1419. United States of America, DC Circuit Court of Appeals, Von Dardel v. Union of Soviet Socialist Republics [1985] 23 F. Supp. 246 (D.D.C. 1985). Greece, Special Supreme Court, Perfectory Voiotia v. Germany (Distomo), 111/2000 (4 May 2000). Italy, Court of Cassation, Ferrini v. Germany, 5044/2004 (11 March 2004); Civitella, 1072/08 (21 October 2008).

31 United States of America, DC Circuit Court of Appeals, Princz v. Federal Republic of Germany [1994] 26 F.3d 1166; United States of America, District Court (New York), Hirsch v State of Israel and State of Germany [1997] 962 F. Supp. 377; United States of America, United States Court of Appeals, $2^{\text {ND }}$ Circuit, Smith v. Socialist People's Libyan Arab Jamahiriya [1996] 101 F.3d 239; United Kingdom, House of Lords, Jones v. Saudi Arabia [2006] UKHL 26; European Court Of Human Rights, Al-Adsani v. the United Kingdom, app. no. 35763/97, 21 November 2001; McElhinney v. Ireland, app. no. 31253/96, 21 November 2001; Kalogeropoulou and Others v. Greece and Germany, app. no. 59021/00, 12 December 2002; Waite and Kennedy v. Germany, app. no. 26083/94, 18 February 1999.

${ }_{32}$ Poland, Białystok Appellate Court, I ACa 833/12 (21 January 2013). The Court referred to Germany, Federal Tribunal [2011] XI ZR 33/10.

33 "It must be added that it results from the judgment of the German Federal Tribunal [2011] XI ZR 33/10, which concerns the scope of information and loyalty obligations of banks towards its clients in connection with contracts of derivate transactions, that a bank should question its client on the investment risk that the client is able to undertake - regardless of client's economic education. The bank should also explain the risk of a 'product', so that the client has the same level of knowledge of a 'product' as a bank itself, it should inform the client about a negative (from their stance), initial pricing of a product, as this pricing itself shows a serious conflict of interests of bank and its client, inform client about the conflict of interests, if the structure of the 'product's' risk is wilfully shifted by bank to the disadvantage of its client. The Federal Tribunal did not connect the information obligations of a bank with a consumer status of its client. Running a business activity by a client
} 
To sum up this sub-chapter, it needs to be emphasized that a proper judicial dialogue requires profound research into decisions of international and foreign courts. It is not a mere citing, it requires deep analysis and a proper comparison of similarities and differences between foreign laws and Polish law in order to make a decision whether this international and foreign jurisprudence can be a source of inspiration on judging a domestic case. A superficial and trivial examination might lead to simplified and wrong conclusions on the interpretation of domestic law. In the above-mentioned cases, Polish courts managed to fulfil these requirements. Those judgments are extremely exceptional, as mostly, courts do no more than simply cite international and foreign judgments without any further deliberations on their content or even their connection to the case at hand administrative courts also need to interpret international law or EU law. One of the examples of a proper judicial dialogue are judgments on the interpretation of the Model Tax Convention on Income and Capital. ${ }^{34}$ Administrative courts needed to interpret the notion of "industrial, commercial or scientific equipment". In numerous judgments ${ }^{35}$ the Supreme Administrative Court referred to the report of the Committee of Experts on International Cooperation in Tax Matters and cited numerous judgments that interpret the notion of "industrial equipment". ${ }^{36}$ Then, the Court compared them with the factual background of the cases to make a decision on taxes.

\subsection{Decorative judicial dialogue}

A decorative dialogue means that courts pretend to refer to the case law of other courts, but in fact, they just decorate the reasoning with random references to inappropriately collected and inaptly analysed decisions. They neither analyse this caselaw, nor indicate what kind of connection of this international and foreign jurisprudence exists with the domestic case at stake.

\footnotetext{
has no influence on bank's information obligations. The crucial aspect for bank information obligations is the lack of sufficient client's knowledge on the evaluation of risks of transaction to the level fundamentally close to bank's knowledge, as far as it concerns given transaction. Client's professional skills are principally of no importance. The Federal Tribunal noted that client's professional experience should be actually connected to preparation and conclusion of derivate transactions, so that the client had practical knowledge on the effects of a given transaction, comparable to the bank's knowledge. A general knowledge on transaction is not enough. Assuming that the client was knowledgeable of risks caused by transaction only on this ground, that client had contracts with other bank, lacks justification. A client's experience, justifying resignation from exhausting information about properties and possible effects of transaction should concern exactly the same transactions, but it does not mean only the type or subtype of it. The remarks of the Federal Tribunal are applicable in Polish reality, as the Tribunal solved the case actually on the basis of general rules of liability for damages ex contractu (§ 280 of the German Civil Code), and partially on the basis of the German statute on securities trading (§ 31.1.2 of the German statute on securities trading), which correspond to Art. 471 of the Polish Civil Code and § 6(1) of the regulation of the Ministry of Finance of 28 December 2005 on the terms and procedures for investment firms and trust banks (O.J. 2006.2.8)."

${ }^{34}$ OECD Model Tax Convention on Income and Capital, Paris, 30.7.1963.

35 Poland, Supreme Administrative Court, II FSK 1395/16 (18 May 2018). Poland, Supreme Administrative Court, II FSK 1477/16 (5 June 2018). Poland, Supreme Administrative Court, II FSK 1540/16 (6 June 2018). Poland, Supreme Administrative Court, II FSK 1773/16 (6 June 2018). Poland, Supreme Administrative Court, II FSK 170/17 (22 January 2019).

36 Singapore, Supreme Administrative Court, E.2011/1367, K.2013/1281 re DTC Turkey/USA (10 April 2013). Malaysia, decision in Commissioners for Her Majesty's Revenue and Customs, judgment of 30.5.1996, OA Pte Ltd v. DGIR, case no. PKR 651, IFBD Case Law re DTC Malaysia/Singapore. India, Income Tax Appellate Tribunal Chennai, West Asia Maritime Ltd. v. DIT [2008] 111 ITD 155, judgment of 19.5.2006. Mexico Décimo Tercer Tribunal Colegiado En Materia Administrativa Del Primer Circuito, case no. D.A. 562/2011-9995, re DTC México/Canada, judgment of 20.8.2012.
} 
It this area, the decision of the Polish Constitutional Tribunal in $\mathrm{K} 33 / 99^{37}$ can be mentioned. This judgment concerned law on road traffic, ${ }^{38}$ namely Art. 65 (7), transferring to the ministry the power to decide on the rules on road safety during public assemblies. The Tribunal made only a decorative reference to the ECtHR judgment in Platform Ärzte für das Leben, ${ }^{39}$ repeating only that states are obliged to take actions to safeguard safety during legal assemblies. It is impossible to say why the Constitutional Tribunal recognized this case as having importance for the legal problem that was placed before the $\mathrm{CT}$, what similarities and differences of this case exist in relation to the domestic case adjudicated by the Tribunal. A mere mentioning of the case by its name did not make the reasoning of the Tribunal any richer and more profound.

Another example of a decorative dialogue of Polish courts was the reference to the Human Rights Committee (HRC) in a decision which concerned family law and the state's obligation to respect one's private and family life, as enshrined e.g. in Art. 17 of the International Covenant on Civil and Political Rights (ICCPR). ${ }^{40}$ In its ruling in case no. II CKN 321/99, ${ }^{41}$ the Supreme Court made solely a superficial remark, that according to the HRC, the prohibition of unlawful interference in one's private life means that no intrusion is permissible, except for the situations strictly regulated by law. The Court did not indicate any specific decision of the Human Rights Committee on Art. 17 ICCPR relevant to the case at stake. The only purpose of this general reference was to add value to its own reasoning. The Court also shortly mentioned Art. $8 \mathrm{ECHR}$ (the right to respect private and family life) and the Polish Constitution (Art. 31 ${ }^{42}$ and Art. 47), ${ }^{43}$ indicating neither decisions of the ECtHR, nor of the Polish Constitutional Tribunal.

This practice is, of course, incorrect and undesirable Courts refer to randomly selected judgments without justifying their choice, sometimes only by mentioning the name of international or foreign court, without indicating its specific judgment. Judgments of domestic courts would be of the same value, if they had no such a mention at all, as it serves no purpose. It is only a useless decoration of courts' reasoning, without any major improvement as to the merits of the case.

\subsection{Failed judicial dialogue}

A failed judicial dialogue takes place if courts miss the opportunity to refer to the case law of other courts all over, where one should reasonably expect that such jurisprudence is presented. This means that there is no dialogue at all in the instances in which, without a doubt, it should be applied. Although it is not a desirable situation, it is extremely difficult to recognize such cases of missed chances, as in order to do that one must know that there exists international and foreign case-law that should be cited in a case in issue, yet this jurisprudence was omitted by a court. This can also be portrayed by the following examples.

The Wroclaw Appellate Court's decision ${ }^{44}$ on lustration proceedings carefully analysed the decisions of the Supreme Court and of the Constitutional Tribunal. It examined the nature of lustration proceedings to determine whether it is of a criminal character, despite the fact that this issue has been already decided by the ECtHR in

\footnotetext{
${ }^{37}$ Poland, Constitutional Tribunal, K 34/99 (28 June 2000).

38 Poland, Law on road traffic of 20 June 1997, Polish Official Journal 1997, no. 98/602.

${ }^{39}$ European Court of Human Rights, Platform Ärzte für das Leben v. Austria, app. no. 10126/82, 21 June 1988.

40 International Covenant on Civil and Political Rights, 999 UNTS 171, 16 December 1966. (ICCPR).

${ }^{41}$ Poland, Supreme Court, II CKN 321/99 (18 August 1999).

42 The principle of proportionality.

${ }^{43}$ The right to respect for private and family life.

44 Poland, Wroclaw Appellate Court, II AKz 542/10 (26 October 2010).
} 
Moczulski v. Poland, ${ }^{45}$ and the Appellate Court barely observed that both the Constitutional Tribunal and the ECtHR consider this procedure to be a criminal one.

Although it would seem natural to refer to judgments of foreign courts on Hague Convention on the Civil Aspects of International Child Abduction, ${ }^{46}$ as it represents a frequent subject of their holdings, including cases against Poland, ${ }^{47}$ the Polish general courts seem to decide on the cases based on this convention by interpreting its provisions solely on the basis of domestic law and case-law.

For example, in I CKN 776/00, ${ }^{48}$ the Polish Supreme Court interpreted the notion of the habitual residence of the child with no reference to any case-law at all. In II Ca $217 / 16^{49}$ the Bialystok Provincial Court made a detailed scrutiny of the judgments of the Polish Supreme Court, whereas, as to the international case law, it made only a decorative reference to the ECtHR's judgment in Neulinger and Shuruk v. Switzerland ${ }^{50}$ stating that the Hague Convention should be interpreted also taking into consideration the UN Convention on the Rights of the Child. ${ }^{51}$ It has to be borne in mind that the meaning of the notion of habitual residence is still being developed. It is a concept taken from an international convention, requiring an analysis to be made on the basis of its international roots, and not solely on the basis of the linguistic interpretation derived from national law. Those Polish courts had a chance to deliberate on the notion of the habitual residence from the perspective of international law, to enter into a dialogue with other courts, especially the European Court of Human Rights, and to participate in the elaboration of principles governing application and understanding of this institution. However, they simply missed the opportunity.

A proper use of international and foreign case-law in domestic judgments requires a higher level of knowledge of the same. This knowledge has to be updated by relevant research. Taking into consideration a variety of material issues that might be decided by a single judge, this requirement can exceed their abilities.

\section{ASSESSMENT OF INTERNATIONAL JUDICIAL DIALOGUE AS A METHOD OF INTERPRETATION USED BY POLISH COURTS}

Polish courts are learning how to participate in international judicial dialogue. Some of them make use of their chance to contribute to the discourse, while others simply miss the opportunity Even the very citing of foreign jurisprudence is problematic. In this chapter, I will first evaluate the accuracy in referring to the international and foreign case-law, and, subsequently, I will discuss the issue whether or not the Polish courts have any influence on the international and foreign judiciary.

\subsection{Correctness}

To be accurate, international judicial dialogue needs to fulfil certain criteria. As one can deduct from the previous part, this can be neither a decorative dialogue, nor a failed one.

\footnotetext{
${ }^{45}$ ECtHR, case no. 49974/08 Moczulski v Poland, judgment of 19.11.2011.

${ }^{46}$ Convention on the Civil Aspects of International Child Abduction, Hague, 25.10.1980.

${ }^{47}$ ECtHR case-law: Oller Kamińska v. Poland, app. no. 28481/12, 18 January 2018; G.N. v. Poland, app. no 2171/14, 19 July 2016; K.J. v. Poland, app. no. 30813/14, 1 March 2016; R.S. v. Poland, app. no. 63777/09, 21 July 2015; Rouiller v. Switzerland, app. no. 3592/08, 22 July 2014; Özgür Uyanik v. Turkey, app. no. 11068/04, 23 March 2010.

${ }^{48}$ Poland, Supreme Court, I CKN 776/00 (26 September 2000).

${ }^{49}$ Poland, Białystok Provincial Court, II Ca 217/16, 15 April 2016.

50 European Court of Human Rights, Neulinger and Shuruk v. Switzerland, app. no. 41615/17, 6 July 2010.

${ }^{51}$ United Nations Convention on the Rights of the Child, New York, 20.11.1989.
} 
Moreover, if a court decides to use the method of legal interpretation, references to international case-law should be exact and precise. Unfortunately, very often this is not the case. For the Polish courts, the most visible problem rests with the adequate citation of international and foreign rulings, sometimes causing even humorous results. The most remarkable example is naming the ECtHR as "the European Court of Human Rights in S." where "S."' stands for "Strasbourg" or "the Court of Justice in L." with "L." meaning "Luxembourg". ${ }^{52}$ The citation often lacks dates of judgments, case numbers or names of parties, although there are legal systems worldwide that commonly apply distinction of cases by parties' names. ${ }^{53}$ These imprecisions, although they can be easily noticed and corrected, may clearly hamper the judicial discourse.

There is no uniformity in references to international and foreign case-law as there are no general rules of citation. On the one hand, courts use original name of the court in foreign language, on the other, they try to translate courts' names into Polish which sometimes produces disputable effect. The most obvious example of this infamous practice is represented by the names of German courts. Here, e.g. the German Constitutional Court (Bundesverfassungsgericht) is described both as a "Court" and as a "Tribunal", although in German language "Gericht" states for a "Court" while "Tribunal" in German reads "Gerichtshof".

The above-mentioned problems make it sometimes impossible to decipher which judgment exactly a Polish court wanted to address. Subsequently, the verification of correctness of a specific reference might become disputable, even impossible. In consequence, this practice might lead to uncontrolled arbitrariness.

\subsection{Influence of Polish case-law on jurisprudence of international and foreign courts}

International judicial dialogue as opposed to monologue represents the core subject of this paper. It requires some level of reciprocity in references to international and foreign case-law. One of the aims of international judicial dialogue is participation of domestic courts in the process of formation of international legal rules and standards. Domestic courts should play not only a passive, receptive role in this dialogue. They should also influence interpretation of law made by international and foreign courts. This part is devoted to influence of Polish judgments on case-law of other courts. First, it will be discussed whether Polish jurisprudence had any effect on customary international law, and then it will be presented that it also was a source of inspiration for courts of Central and Eastern Europe.

\footnotetext{
52 Łódź Appellate Court, I ACa 931/14 (30 December 2014): "Wprawdzie w orzecznictwie Europejskiego Trybunału Praw Człowieka w S. oraz Sądu Najwyższego, język i forma wypowiedzi prasowych podlegają ochronie, ale jednak w granicach prawa do czci tak jak swoboda wypowiedzi". Białystok Appellate Court, I ACa 617/13 (20 December 2013): "Orzecznictwo Europejskiego Trybunału w S."

${ }^{53}$ For example: Łódź Appellate Court, I ACa 662/12 (1 October 2012): "orzeczenie z dnia 26 kwietnia 1979 r. W sprawie [...] v. Wielka Brytania (I), skarga [...], LEX nr 80817; orzeczenie z dnia 23 maja 1991 r. w sprawie O. v. Austria, skarga [...], LEX nr 81177; orzeczenie z dnia 8 lipca 1986 r. w sprawie L. v. Austria, skarga [...], LEX nr 81012". Supreme Court, IV CS 202/13 (28.2.2014): "Sprawa mieści się więc w pojęciu sprawy cywilnej i handlowej, rozumianej w sposób ugruntowany w orzecznictwie Trybunału Sprawiedliwości (por. np. wyrok ETS z dnia 14 listopada 2002 r., C-271/00 Slg. 2002, I-10489)". Warsaw Appelate Court, I ACa 1166/13 (11 March 2014): "tak m.in. wyrok Trybunału Sprawiedliwości z 10 kwietnia 1984 r. w sprawie 14/83 von C., pkt 26; wyrok z 13 listopada 1990 r. w sprawie C-106/89 M., pkt 8; wyrok z 5 października 2004 r. w połączonych sprawach C-397/01 do C-403/01 P. i in., pkt 113 i 115". It is worth noticing that "wyrok Trybunału Sprawiedliwości z 10 kwietnia 1984 r. w sprawie 14/83 von C." means the CJEU case 14/83 Von Colson and Kamann v. Land Nordrhein-Westfalen, judgment of 10.4.1984, which is a very well-known and recognizable judgment of the CJEU.
} 


\subsubsection{Customary international law}

Polish jurisprudence had influence on customary international law in the area of state immunity, as this matter is mostly regulated by international custom.

The previously mentioned Supreme Court's judgment in Natoniewski was noticed by the International Court of Justice in its decision in Jurisdictional Immunities of the State (Germany $v$ Italy: Greece Intervening $)^{54}$ and by the European Court of Human Rights in Jones and Others $v$ the United Kingdom. ${ }^{55}$ The ICJ in its ruling agreed with the Polish Supreme Court that the Basel Convention ${ }^{56}$ does not cover the immunity of a state for the acts of its armed forces. Afterwards, the ICJ described in detail the reasons, why the Polish Supreme Court decided that Germany had jurisdictional immunity in cases concerning the acts committed during World War II. The ICJ emphasized that the Polish Supreme Court was one of the bodies presenting opinion that state immunity does not depend on the gravity of the act of which it is accused, or the peremptory nature of the rule which it is alleged to have violated.

The judgment of the ECtHR concerned the right to a fair trial (Art. 6 ECHR). The applicants claimed they had been tortured in the Kingdom of Saudi Arabia by its officials, what constitutes a violation of a peremptory norm, and brought civil claims before the courts of the United Kingdom. The ECtHR was provided by the applicants and the United Kingdom with a comparative material on the practice of 21 Members of the Council of Europe, including also the decision in Natoniewski. Yet, for the ECtHR, the decisive factor was the judgment of the ICJ in Jurisdictional Immunities of the State (Germany $v$ Italy: Greece Intervening).

However, this is not the first Polish judgment on state immunity referred to by foreign courts. In its judgment in $2 \mathrm{BmV} 1 / 62^{57}$ the German Federal Constitutional Court, in determining customary international law on state immunity, cited the decisions of the Polish Supreme Court in R 133/26, ${ }^{58}$ in II C 413/37, ${ }^{59}$ in C 365/48, ${ }^{60}$ and in II CR 172/56. ${ }^{61}$

\subsubsection{Influence on courts of Central and Eastern Europe}

Among courts of other states of Central and Eastern Europe Polish courts were referred to by Czech and Slovak Constitutional Courts.

In case concerning judicial review of security clearances, ${ }^{62}$ the Czech Constitutional Court analysed the decision of the Polish Constitutional Tribunal in K. $21 / 99^{63}$ in a very detailed and meticulous way. The Czech court referred to specific paragraphs of the Polish judgment, to the norms of the Polish Constitution, and to the Polish statutory regulations in the investigated area. It came to the result that the right to a fair trial should be also granted to persons subject to security clearance, and those persons cannot be deprived of their right of access to courts.

\footnotetext{
${ }^{54}$ International Court of Justice, Jurisdictional immunities of the State (Germany v Italy: Greece intervening, judgment, 2012 I.C.J. Rep. 99, (3 February).

${ }_{55}^{5}$ ECtHR, case no. 34356/06 and 40528/06 Jones and Others v the United Kingdom, judgment of 14.1.2014.

${ }^{56}$ European Convention on State immunity, Basel, 16.5.1972.

${ }^{57}$ Germany, Federal Constitutional Court [1963] 2 BmV 1/62.

58 Polish Supreme Court, R 133/16 (2 March 1926), translated into German in Zeitschrift für Ostrecht 1927, p. 275.

${ }_{59}$ Polish Supreme Court, II C 413/37 (31 August 1937).

60 Polish Supreme Court, C 365/48 (14 December 1948), translated into English in International Law Review 1957, p. 223.

${ }^{61}$ Polish Supreme Court, II CR 172/56 (26 March 1958), translated into English in International Law Review, Bd. $26(1958$ - II), p. 178.

62 Czechia, Constitutional Court, PI. ÚS 11/04, (26 April 2005).

${ }^{63}$ Poland, Constitutional Tribunal, K 21/99 (10 May 2000).
} 
Polish constitutional jurisprudence was also noticed by the Czech Constitutional Court in its judgment on judges' salaries. ${ }^{64}$ From the decisions of the Polish Constitutional Tribunal in $\mathrm{P} 1 / 94,{ }^{65} \mathrm{~K} 13 / 94,{ }^{66} \mathrm{P} 1 / 95^{67}$ and $\mathrm{P} 8 / 00,{ }^{68}$ the Czech Court deduced that judges' salaries must correspond with the dignity of their office and ensure fulfilment of their obligations. Moreover, if the state has budget difficulties, judges' salaries are to be protected from "excessive unfavourable fluctuation" and it is impermissible to lower the pay of judges, which, according to the court, is "exceptionally strongly protected by the Constitution". As a conclusion, the Czech Court noticed that an interference in the material security of judges guaranteed by law may not be an expression of arbitrariness by the legislature, but must be, based on the principle of proportionality, justified by extraordinary circumstances, e.g. by the state's difficult financial situation, and even if this condition is met, account must be taken of the different function of judges and that of representatives of the legislative and executive branches, especially the state administration. Such interference may not create grounds for concerns that it may limit the dignity of judges, or that it may be an expression of constitutionally unacceptable pressure by the legislative and executive branches on the judicial branch.

In case concerning the Treaty of Lisbon $1^{69}$ the Czech Constitutional Court referred to the decision of the Polish Constitutional Court in $\mathrm{K} 18 / 04,{ }^{70}$ to the extent that it analysed the limits of the conferral of powers to the European Union. The Czech Court made a critical examination of the Polish judgment and concluded that the Polish Constitutional Tribunal expressly rules out the jurisdiction of the CJEU to evaluate the limits of conferral of competences on the EU. According to the Polish Tribunal, that is a question of interpretation of domestic constitutional law. The Czech Court agreed with this opinion in terms of the dogmatics of domestic constitutional law and to a certain extent. However, according to the Czech Constitutional Tribunal, it is questionable whether it is necessary to formulate this opinion as sharply as the Polish Tribunal did.

Another court of Central and Eastern Europe that makes references to Polish case-law is the Slovak Constitutional Court. ${ }^{71}$ Just as the Czech Court, it had to decide on regulations of judges' salaries. In the comparative part, citing the US Constitution, the Court stated that in the Slovak Constitution there is no explicit guarantee of judges' remuneration. In comparison, the Slovak Court emphasized that the Polish Constitution has a more explicit guarantee in Art. 178(2) than the Slovak Constitution, yet the Polish Constitutional Tribunal has accepted, in a limited scope, some modifications of judges' remuneration in decisions in $\mathrm{K} 12 / 03,{ }^{72}$ in $\mathrm{K} 1 / 12{ }^{73}$ in $\mathrm{K} 13 / 94^{74}$ and in $\mathrm{P} 8 / 00 .^{75}$

To sum up this part of the paper, it is worth underlining that international judicial dialogue between states in Central and Eastern Europe may be a way to influence regional and international case-law. These states usually have similar historical background, they have their own experience with socialism. By mutual references between courts of these states, their common voice is more likely to be noticed and taken into consideration by the international community. This would permit Central and Eastern Europe courts to

\footnotetext{
${ }^{64}$ Czechia, Constitutional Court, PI. ÚS 11/04, (26 April 2005).

65 Poland, Constitutional Tribunal, P 1/94 (8 November 1994).

66 Poland, Constitutional Tribunal, K 13/94 (14 March 1995).

${ }_{67}$ Poland, Constitutional Tribunal, P 1/95 (11 September 1995)

68 Poland, Constitutional Tribunal, P 8/00 (4 October 2000).

${ }^{69}$ Czechia, Constitutional Court, PI. ÚS 19/08 (26 November 2011).

70 Poland, Constitutional Tribunal, K 18/04 (11 May 2005).

${ }^{71}$ Slovakia, Constitutional Court, PI. ÚS 99/11 (11 December 2013).

72 Poland, Constitutional Tribunal, K 12/03 (18 February 2004).

73 Poland, Constitutional Tribunal, K 1/12 (12 December 2012).

${ }^{74}$ Poland, Constitutional Tribunal, K 1/12 (12 December 2012).

${ }^{75}$ Poland, Constitutional Tribunal, K 13/94 (14 March 1995).
} 
change their position among courts of the world from receptive into affecting jurisprudence of other judicial bodies.

\section{CONCLUSION}

Undoubtedly, international judicial dialogue is a tempting method of interpreting international and national law as it brings new and attractive ideas to national courts. On the other hand, there are characteristics of this method that make its application quite problematic and require solutions permitting minimalizing the risks connected thereto.

First, it needs to be indicated what the advantages of this interpretive method are, as they make it worth a further development and may make courts more inclined to apply international judicial dialogue. This technique can be used by all types and levels of judiciary, including civil, penal and administrative courts, from the lowest level (in Poland district courts or voivodship administrative courts) to the highest one (in Poland: the Constitutional Tribunal, the Supreme Court and the Supreme Administrative Court). International judicial dialogue permits a multidimensional analysis of law and verification and critical analysis of national courts' own views. One needs to remember that it is not always necessary to look forcibly for some new interpretation only to permit national courts to be original in their application of law. If a wheel has already been invented, so if there exists a logical and verified solution to a given legal problem, the best way to solve a problem within the national law framework might be to apply the confirmed international patterns. ${ }^{76}$

Therefore, international judicial dialogue might protect a state from its responsibility at the international level (e.g. before the European Court of Human Rights for violations of fundamental rights enshrined in the European Convention of Human Rights), as it permits verification and application of common standard of interpretation. It also strengthens the rule of law and international cooperation, as well as mutual trust between different jurisdictions, what, on its side, facilitates international commerce and international relations by creating commonly accepted rules.

By taking part in the international judicial dialogue, national courts can equally shape customary international law, interpretation of international agreements and human rights law standards. That reflects a desire of domestic courts to play an authoritative role in the formation of international legal rules and standards (Grove, 2001, p. 2061, 2071). If a court fails to take part in international judicial dialogue, it risks a growing isolation and diminished influence. According to L'Heureux-Dubé, this is exactly the case of U.S. courts, as they situate themselves outside international debates and discussions (1998, p. 37-38).

Nevertheless, drawbacks of this method might seriously hamper its application by national courts. It must be noticed that not all foreign solutions can be adapted to national law standards due to differences in political and social realties, values and traditions (L'Heureux-Dubé, 1998, p. 26). Therefore, solutions stemming from common law countries cannot always be applied in states that have legal systems based on Roman law. Legal solutions existing in Europe might be unsuitable for states in other parts of the world. There are also legal differences between law systems of states in Central and Eastern Europe, formerly having socialist laws, and other European states.

Probably the major weakness of international judicial dialogue is national judges insufficient knowledge of international law and case-law, and sometimes even of foreign languages (L'Heureux-Dubé, 1998, p. 21). This may lead to very serious consequences, including the inability to verify laws, opinions and interpretations of different jurisdictions

\footnotetext{
${ }^{76}$ As Kirby noted, good ideas are not necessarily home grown (Kirby, 2008, p. 184).
} 
and also to misinterpretation of foreign case-law. Since nowadays in the international community, English is the most widely spoken language, both as mother tongue and foreign language, there exists an increased level of probability that common law judgments and interpretations of law will dominate this technique. Moreover, there might occur instances of cherry-picking application of foreign judgments either by a selective choice of national judges, restricted by their knowledge of foreign law and languages, or by a selective choice of foreign judgments made by foreign authorities that decide to translate particular case-law in the most commonly spoken languages like English, French, Spanish, Russian or German. One of the minor consequences hampering international judicial dialogue and verification of information is also an improper citation of foreign judgments which hinders one from finding an adequate source of confirmation of text of foreign case-law, namely the judgments themselves.

One disadvantage is typical for states of Central and Eastern Europe or other states with reliably smaller importance in international community of states. Their own case-law has a very limited influence on international and foreign judgments, whereas the judgments of their own courts are rather receptive, ${ }^{77}$ meaning that they adapt their interpretation to the one made by foreign instances. This problem is slightly mitigated, if international and foreign case-law is ample and even a common standard of interpretation has been already established.

Yet, in relation to specific legal problem, the examples of international and foreign solutions might be scarce, as the issue is relatively new and it still needs to be examined. The very first opinions might neither be correct nor contain a profound analysis of the question in question. If there are more of them, they might be unknown to international community simply because of their non-existent translation into commonly used languages. This raises some serious doubts whether these few opinions known to international community should be followed by national courts.

The Polish Constitutional Tribunal pointed at some of the above-mentioned problems in its judgment in K 38/07: "The need for references to foreign judicial decisions results from the fact of approximation of contemporary legal systems, however, it must be done with the reservation that it requires fulfilment of different conditions and awareness of different context. Extra-linguistic methods of interpretation are subsidiary to linguistic and logical interpretation of law. For the proper interpretation of domestic legislation with the use of international judicial dialogue, it is necessary to establish the adequacy of foreign patterns for the interpretation of the Polish law. There needs to exist an extreme caution in choosing a legal system to which a reference is made."78

Some of these problems might be partially softened, however, not totally eliminated. One of the solutions is a unification of citing, in the meaning of creation common international rules of citing of international and national judgments, as currently this problem is dependent totally on states, their courts and ways of publications used by legal scholars. ${ }^{79}$ There exist attempts to create such common system, one of them is OSCOLA system (Nolan and Meredith, 2012), another is the Bluebook (Miles Prince, 2015). Germany has its own citation system in a form of an ISO norm. ${ }^{80}$

Another important way, especially for states like Central and Eastern European states, is to create collections of translations of high quality domestic judgments on significant issues into world languages. For example, the Constitutional Court of Slovenia

\footnotetext{
77 Whereas the dialogue and its influence should be reciprocal (L'Heureux-Dubé, 1998, p. 27).

78 Poland, Constitutional Tribunal, P 38/07 (3 July 2008).

${ }^{79}$ New York University School of Law. (2006). Guide to foreign and international legal citations

80 Deutsches Institut für Normung E. V. Information und Dokumentation - Richtlinien für Titelangaben und Zitierung von Informationsressourcen (ISO 690:2010).
} 
prepared such collection. ${ }^{81}$ More attention should be put to judicial comparativism during legal studies and lawyers' professional training as well, including not only judges but also prosecutors and attorneys. Moreover, it is also a task for legal doctrine to create more comparative analyses with proper citation of judgments, as the publications of legal scholars are commonly used by national judges as a source of information about foreign case-law.

\section{BIBLIOGRAPHY:}

Biuletyn Informacji Publicznej. Lista sądów powszechnych. Retrieved from: https://dane.gov.pl/dataset/985,lista-sadowpowszechnych/resource/3873/table (31.12.2019).

Cambridge Dictionary. Definition of "dialogue" Retrieved from: https://dictionary.cambridge.org/dictionary/english/dialogue (31.12.2019).

Collins Dictionary. Definition of "dialogue" Retrieved from: https://www.collinsdictionary.com/dictionary/english/dialogue (31.12.2019).

Czaplińska, A. (2017). The Preliminary Reference Procedure as an Instrument of Judicial Dialogue in the EU - the CEE Perspective. In A. Wyrozumska (Ed.), Transnational Judicial Dialogue on International Law in Central and Eastern Europe (pp. 297332). Łódź: Łódź University Press. Retrieved from https://doi.org/10.18778/8088-707-7.06.

Constitutional Court of the Republic of Slovenia. (2016). Selected Decisions 1991-2015. Ljubljana: Constitutional Court of the Republic of Slovenia. ISBN: 978-961-905895-4.

Deutsches Institut Für Normung E. V. Information und Dokumentation - Richtlinien für Titelangaben und Zitierung von Informationsressourcen (ISO 690:2010).

Górski, M. (2017). The Dialogue between Selected CEE Courts and the ECtHR. In A. Wyrozumska (Ed.), Transnational Judicial Dialogue on International Law in Central and Eastern Europe (p. 503). Łódź: Łódź University Press. Retrieved from https://doi.org/10.18778/8088-707-7.05.

Grove, T.L. (2001). The International Judicial Dialogue: When Domestic Constitutional Courts Join the Conversation. Harvard Law Review, Vol. 114 (1), 2049-2073.

L'Heureux-Dubé, C. (1998). The Importance of Dialogue: Globalization and the International Impact of the Rehnquist Court. Tulsa Law Review, Vol. 34 (1), 15-40.

Matusiak-Frącczak, M. (2017). The Polish Ordinary Courts in Dialogue on International Law. In A. Wyrozumska (Ed.), Transnational Judicial Dialogue on International Law in Central and Eastern Europe (pp. 333-364). Łódź: Łódź University Press. Retrieved from https://doi.org/10.18778/8088-707-7.07.

Kirby, M. (2008). Transnational judicial dialogue, internationalisation of law and Australian judges. Melbourne Journal of International Law, Vol. 9 (6), 171-189.

Krzemińska-Vamvaka, J. (2017). Administrative Courts and Judicial Comparativism in Central and Eastern Europe. In A. Wyrozumska (Ed.), Transnational Judicial Dialogue on International Law in Central and Eastern Europe (pp. 197-232). Łódź: Łódź University Press. Retrieved from https://doi.org/10.18778/8088-707-7.04.

Law, D.S. and Chang, W.-C. (2011). The limits of global judicial dialogue. Washington Law Review, Vol. 86, 523-577.

\footnotetext{
81 Constitutional Court of the Republic of Slovenia. Constitutional Court of the Republic of Slovenia: Selected Decisions 1991-2015. Ljubljana: The Constitutional Court of the Republic of Slovenia 2016.
} 
Merriam-Webster Dictionary. Definition of "dialogue" Retrieved from: https://www.merriam-webster.com/dictionary/dialogue (31.12.2019).

Meuwese, A. and Snel, M. (2013). 'Constitutional Dialogue': An Overview. Utrecht Law Review, Vol. 9 (2), 123-140. Retrieved from http://doi.org/10.18352/ulr.231

Miles Prince, M. (Ed.). (2015). The Bluebook: A Uniform System of Citation. 20th edition. Harvard: Harvard Law Review Association.

New York University School Of Law. (2006). Guide to foreign and international legal citations. Retrieved from:

https://www.law.nyu.edu/sites/default/files/upload_documents/Final_GFILC_pdf .pdf (31.12.2019).

Nolan, D. and Meredith, S. (2012). OSCOLA: Oxford University Standard for the Citation of Legal Authorities. 4th edition. Oxford: Hart.

Oxford Learner's Dictionary. Definition of "dialogue" Retrieved from: https://www.oxfordlearnersdictionaries.com/definition/english/dialogue (31.12.2019).

Skomerska-Muchowska, I. (2017). The Dialogue of CEE Constitutional Courts in the Era of Constitutional Pluralism. In A. Wyrozumska (Ed.), Transnational Judicial Dialogue on International Law in Central and Eastern Europe (pp. 103-196). Łódź: Łódź University Press. Retrieved from https://doi.org/10.18778/8088-707-7.03.

Thesaurus Dictionary. Definition of „dialogue” Retrieved from: https://www.dictionary.com/browse/dialogue (31.12.2019).

Convention on the Civil Aspects of International Child Abduction, Hague, 25.10.1980.

European Convention on State immunity, Basel, 16.5.1972.

International Covenant on Civil and Political Rights, 16 December 1966.

OECD Model Tax Convention on Income and Capital, Paris, 30.7.1963.

United Nations Convention on the Rights of the Child, New York, 20.11.1989.

International Court of Justice, Case concerning the arrest warrant of 11 April 2000

(Democratic Republic of the Congo v Belgium), judgment, 2002 I.C.J. Rep. 3 (14 February).

International Court of Justice, Jurisdictional immunities of the State (Germany v Italy: Greece intervening, judgment, 2012 I.C.J. Rep. 99, (3 February).

Court of Justice of the European Union, judgment of 15 February 2007, Lechouritou, C292/05, ECLI:EU:C:2007:102.

Court of Justice of the European Union, judgment of 21 April 1993, Volker Sonntag, C172/91, ECLI:EU:C:1993:144.

European Court of Human Rights, Aksoy v. Turkey, app. no. 21987/93, 18 December 1996.

European Court Of Human Rights, Al-Adsani v. the United Kingdom, app. no. 35763/97, 21 November 2001.

European Court Of Human Rights, Al-Adsani v. the United Kingdom, app. no. 35763/97,

21 November 2001, joint dissenting opinion of judges Rozakis and Caflish, joined by judges Wildhaber, Costa, Cabral Barreto and Vajić.

European Court of Human Rights, Ergi v. Turkey, app. no. 23818/94, 28 July 1998.

European Court of Human Rights, G.N. v. Poland, app. no. 2171/14, 19 July 2016.

European Court of Human Rights, James and Webster v. United Kingdom, app. no. 7601/76, 7806/77, 13 August 1982.

European Court of Human Rights, Jones and others v. United Kingdom, app. nos. 34356/06 and 40528/06, 14 January 2014.

European Court of Human Rights, Kalogeropoulou and Others v. Greece and Germany, app. no. 59021/00, 12 December 2002. 
European Court of Human Rights, Kelly and Others v. UK, app. no. 30054/96, 4 May 2001.

European Court of Human Rights, K.J. v. Poland, app. no. 30813/14, 1 March 2016.

European Court of Human Rights, Marcx v. Belgium, app. no. 6833/74, 13 June 1979.

European Court of Human Rights, McElhinney v. Ireland, app. no. 31253/96, 21 November 2001.

European Court of Human Rights, Moczulski v. Poland, app. no. 49974/08, 19 November 2011.

European Court of Human Rights, Neulinger and Shuruk v. Switzerland, app. no. 41615/17, 6 July 2010.

European Court of Human Rights, Oller Kamińska v. Poland, app. no. 28481/12, 18 January 2018.

European Court of Human Rights, Özgür Uyanik v. Turkey, app. no. 11068/04, 23 March 2010.

European Court of Human Rights, Platform Ärzte für das Leben v. Austria, app. no. 10126/82, 21 June 1988.

European Court of Human Rights, Rouiller v. Switzerland, app. no. 3592/08, 22 July 2014.

European Court of Human Rights, R.S. v. Poland, app. no. 63777/09, 21 July 2015.

European Court of Human Rights, Velikova v. Bulgaria, app. no. 41488/98, 18 May 2000.

European Court of Human Rights, Waite and Kennedy v. Germany, app. no. 26083/94, 18 February 1999.

Austria, Austrian Constitutional Tribunal, SV 2/08, G 80/08 (30 September 2008).

Czechia, Constitutional Court, PI. ÚS 11/04, (26 April 2005).

Czechia, Constitutional Court, PI. ÚS 19/08 (26 November 2011).

France, Constitutional Council, 2007-560 DC (20 December 2007).

France, Court of Cassation, 00-87215 Qaddafi (13 March 2001).

Germany, Federal Tribunal [2011] XI ZR 33/10.

Germany, Federal Constitutional Court [1963] 2 BmV 1/62.

Germany, Federal Constitutional Court [2006] 1 BvR 357/05.

Germany, Federal Constitutional Court [2009] 2 BvE 2/08, 2 BvE 5/08, 2 BvR 1010/08, 2 BvR 1022/09, 2 BvR 1259/08, and 2 BvR 182/09.

Greece, Special Supreme Court, Perfectory Voiotia v. Germany (Distomo), 111/2000 (4 May 2000).

Greece, Special Supreme Court, Margellos v. Germany, 6/2002 (17 September 2002).

Hungary, Constitutional Court, 143/2010 (12 July 2010).

India, Income Tax Appellate Tribunal Chennai, West Asia Maritime Ltd. v. DIT [2008] 111 ITD 155.

Israel, Supreme Court, Public Committee Against Torture on Israel v. The State of Israel et al., Case HCJ 5100/94.

Israel, Supreme Court, The Center for the Defence of the Individual v. The Commander of IDF Forces in the West Bank, Case HCJ 3278/01.

Israel, Supreme Court, Marab v. The Commander of IDF Forces in the West Bank, Case HCJ 3239/02.

Italy, Court of Cassation, Ferrini v. Germany, 5044/2004 (11 March 2004).

Italy, Court of Cassation, Civitella, 1072/08 (21 October 2008).

Latvia, Constitutional Tribunal of Latvia, 2008-35-01 (7 April 2009).

Malaysia, decision in Commissioners for Her Majesty's Revenue and Customs, OA Pte Ltd v. DGIR, case no. PKR 651, IFBD Case Law re DTC Malaysia/Singapore (30 May 1996). 
Mexico Décimo Tercer Tribunal Colegiado En Materia Administrativa Del Primer

Circuito, D.A. 562/2011-9995, re DTC México/Canada (20 August 2012).

Poland, Law on aviation of 3 July 2002, Polish Official Journal 2002, no. 130/1112.

Poland, Law on road traffic of 20 June 1997, Polish Official Journal 1997, no. 98/602.

Poland, Białystok Provincial Court, II Ca 217/16, 15 April 2016.

Poland, Białystok Appellate Court, I ACa 833/12 (21 January 2013).

Poland, Białystok Appellate Court, I ACa 617/13 (20 December 2013).

Poland, Łódź Appellate Court, I ACa 662/12 (1 October 2012)

Poland, Łódź Appellate Court, I ACa 931/14 (30 December 2014).

Poland, Warsaw Appelate Court, I ACa 1166/13 (11 March 2014).

Poland, Wroclaw Appellate Court, II AKz 542/10 (26 October 2010).

Poland, Supreme Court, R 133/16 (2 March 1926).

Poland, Supreme Court, II C 413/37 (31 August 1937).

Poland, Supreme Court, C 365/48 (14 December 1948).

Poland, Supreme Court, II CR 172/56 (26 March 1958).

Poland, Supreme Court, II CKN 321/99 (18 August 1999).

Poland, Supreme Court, I CKN 776/00 (26 September 2000).

Poland, Supreme Court, IV CS 202/13 (28.2.2014).

Poland, Supreme Administrative Court, II FSK 1395/16 (18 May 2018).

Poland, Supreme Administrative Court, II FSK 1477/16 (5 June 2018).

Poland, Supreme Administrative Court, II FSK 1540/16 (6 June 2018).

Poland, Supreme Administrative Court, II FSK 1773/16 (6 June 2018).

Poland, Supreme Administrative Court, II FSK 170/17 (22 January 2019).

Poland, Constitutional Tribunal, P 1/94 (8 November 1994).

Poland, Constitutional Tribunal, K 13/94 (14 March 1995).

Poland, Constitutional Tribunal, P 1/95 (11 September 1995).

Poland, Constitutional Tribunal, K 21/99 (10 May 2000).

Poland, Constitutional Tribunal, K 34/99 (28 June 2000).

Poland, Constitutional Tribunal, P 8/00 (4 October 2000).

Poland, Constitutional Tribunal, K 12/03 (18 February 2004).

Poland, Constitutional Tribunal, K 18/04 (11 May 2005).

Poland, Constitutional Tribunal, P 38/07 (3 July 2008).

Poland, Constitutional Tribunal, K 23/11 (30 September 2008).

Poland, Constitutional Tribunal, K 32/29 (24 November 2009).

Poland, Constitutional Tribunal, K 1/12 (12 December 2012).

Slovakia, Constitutional Court, PI. ÚS 99/11 (11 December 2013).

Singapore, Supreme Administrative Court, E.2011/1367, K.2013/1281 re DTC

Turkey/USA (10 April 2013).

United Kingdom, House of Lords, Commissioner of Police for the Metropolis and Others, Ex Parte Pinochet [1999] UKHL 17.

United Kingdom, House of Lords, A v. Secretary of State for the Home Department [2005] UKHL 71.

United Kingdom, House of Lords, Jones v. Saudi Arabia [2006] UKHL 26.

United States of America, District Court (New York), Hirsch v State of Israel and State of Germany [1997] 962 F. Supp. 377.

United States of America, DC Circuit Court of Appeals, Von Dardel v. Union of Soviet Socialist Republics [1985] 623 F. Supp. 246 (D.D.C. 1985).

United States of America, DC Circuit Court of Appeals, Princz v. Federal Republic of Germany [1994] 26 F.3d 1166.

United States of America, United States Court of Appeals, $2^{\text {ND }}$ Circuit, Smith v. Socialist People's Libyan Arab Jamahiriya [1995] 886 F. Supp. 306. 
United States of America, United States Court of Appeals, $9^{T H}$ Circuit, Liu v. Republic of China [1989] 892 F.2d 1419.

United States of America, Supreme Court of the United States, Republic of Austria v. Altmann [2004] 03-13, 541 U.S. 677 (2004) 327 F.3d 1246.

United States of America, Supreme Court of the United States, Rasul v. Bush [2004] 03334, 542 US 466 (2004) 321 F. 3d 1134. 
